\title{
Anti-Toxoplasma gondii antibodies in pregnant women and their newborn infants in the region of São José do Rio Preto, São Paulo, Brazil
}

\author{
Anticorpos anti-Toxoplasma gondii em gestantes e seus neonatos na região de \\ São José do Rio Preto, São Paulo, Brazil
}

Cinara de Cássia Brandão de Mattos', Lígia Cosentino Junqueira Franco Spegiorin", Cristina da Silva Meira"l', Thaís da Costa Silva"', Ana lara da Costa Ferreiralv, Fabiana Nakashimalv, Vera Lúcia Pereira-Chioccolav", Luiz Carlos de Mattos"vi

Immunogenetics Laboratory, Department of Molecular Biology, Faculdade de Medicina de São José do Rio Preto (Famerp), São José do Rio Preto, São Paulo, Brazil

'MSc. Doctoral student in Health Sciences, Immunogenetics Laboratory, Department of Molecular Biology, Faculdade de Medicina de São José do Rio Preto (Famerp), São José do Rio Preto, São Paulo, Brazil.

"MD, MSc. Doctoral student in Health Sciences, Department of Gynecology and Obstetrics, Faculdade de Medicina de São José do Rio Preto (Famerp), Hospital de Base, Fundação Faculdade Regional de Medicina (Funfarme), São José do Rio Preto, São Paulo, Brazil.

"'MSc. Doctoral student in Sciences, Instituto Adolfo Lutz, São Paulo, Brazil.

"MSc. Immunogenetics Laboratory, Department of Molecular Biology, Faculdade de Medicina de São José do Rio Preto (Famerp), São José do Rio Preto, São Paulo, Brazil.

'PhD. Scientific Researcher, Laboratory of Molecular Biology of Parasites, Instituto Adolfo Lutz, São Paulo, Brazil.

viphD. Full Professor, Immunogenetics Laboratory, Department of Molecular Biology, Faculdade de Medicina de São José do Rio Preto (Famerp), São José do Rio Preto, São Paulo, Brazil.

\section{KEY WORDS:}

Toxoplasma gondii.

Serologic tests.

Pregnancy, high-risk.

Prenatal diagnosis.

Neonatal screening.

\section{PALAVRAS-CHAVE:}

Toxoplasma gondii.

Testes sorológicos.

Gravidez de alto risco.

Diagnóstico pré-natal.

Triagem neonatal.

\section{ABSTRACT}

CONTEXT AND OBJECTIVE: Toxoplasmosis transmission during pregnancy can cause severe sequelae in fetuses and newborns. Maternal antibodies may be indicators of risk or immunity. The aim here was to evaluate seropositivity for anti-Toxoplasma gondii (anti-T. gondii) immunoglobulin M (IgM) and immunoglobulin $\mathrm{G}(\mathrm{lgG})$ antibodies and IgG avidity in pregnant women and their newborn infants.

DESIGN AND SETTING: Cross-sectional study in a high-risk pregnancy outpatient clinic.

METHODS: Serum samples from pregnant women $(n=87)$ and their respective newborns $(n=87)$ were evaluated for anti-T. gondii antibodies using indirect immunofluorescence (IIF) (IgM and IgG), enzymelinked immunosorbent assay (ELISA) (IgG) and an avidity test.

RESULTS: Anti-T. gondii antibodies were identified in $64.4 \%$ of the serum samples from the mothers and their infants (56/87). Except for two maternal serum samples (2.3\%), all others were negative for anti-T. gondii IgM antibodies, using IIF. The results showed that $92.9 \%$ of the pregnant women had high IgG avidity indexes (> 30\%) and four samples had avidity indexes between 16 and 30\%. Two women in the third trimester of pregnancy were positive for anti-T. gondii IgM antibodies; their babies had avidity indexes between 16 and 30\%. The avidity indexes of serum from the other 83 newborns were similar to the results from their mothers.

CONCLUSIONS: The results showed that $2 \%$ of the pregnant women were at risk of T. gondii transmission during the gestational period. These data seem to reflect the real situation of gestational toxoplasmosis in the northwestern region of the state of São Paulo.

\section{RESUMO}

CONTEXTO E OBJETIVOS: A toxoplasmose, quando transmitida durante a gestação, pode causar graves sequelas em fetos e neonatos. Anticorpos maternos podem ser indicadores de risco ou de imunidade. $\mathrm{O}$ objetivo foi avaliar a positividade dos anticorpos das classes imunoglobulina M (IgM) e imunoglobulina G ( $\mathrm{lgG}$ ) anti-Toxoplasma gondii (anti-T. gondii), bem como a avidez de lgG em gestantes e seus neonatos. TIPO DE ESTUDO E LOCAL: Estudo transversal em ambulatório de gestação de alto risco.

MÉTODOS: Anticorpos anti-T. gondii foram avaliados em amostras de soro de gestantes ( $n=87)$ e seus respectivos neonatos ( $n=87$ ) com o uso dos métodos imunofluorescência indireta (IFI) (IgM e lgG), ensaio imunoenzimático (ELISA) (lgG) e avidez.

RESULTADOS: Anticorpos anti-T. gondii foram identificados em 64,4\% das amostras de soro das mães e seus bebês (56/87). Com exceção de duas amostras de soro materno (2,3\%), todas as demais foram negativas anticorpos IgM anti-T. gondii determinado pela IFI. Os resultados mostraram que $92,9 \%$ das gestantes tinham índices elevados de avidez de lgG (> 30\%) e 4 amostras apresentaram índices de avidez entre 16$30 \%$. Duas gestantes no terceiro trimestre da gravidez eram positivas IgM anti-T. gondii; seus bebês apresentaram índices de avidez entre 16 e 30\%. Os índices de avidez dos soros dos outros 83 recém-nascidos foram semelhantes àqueles encontrados nas amostras maternas.

CONCLUSÕES: Os resultados mostraram que $2 \%$ das gestantes estavam sob risco de transmissão de T. gondii durante o período gestacional. Estes dados parecem refletir a real situação da toxoplasmose gestacional na região noroeste do Estado de São Paulo. 


\section{INTRODUCTION}

Toxoplasmosis is a zoonosis caused by Toxoplasma gondii, an obligate intracellular protozoan parasite within the apicomplexa classification that can infect many different species of mammals and birds. Humans can be infected by consumption of raw or undercooked red meat or vegetables, unpasteurized milk or contaminated water, or after contact with cat feces. ${ }^{1}$ Additionally, fetuses can be infected by transplacental transmission, a condition that may cause significant sequelae in babies. The life cycle of toxoplasmosis is shown in Figure 1.

During acute infections, the parasites differentiate within tissue cysts in the muscles and brain. Most primary infections are asymptomatic and, in fact, only $10-20 \%$ of all patients infected by T. gondii are symptomatic. In these cases, toxoplasmosis can be a serious public health problem. ${ }^{2,3}$

Fetuses of women acutely infected during pregnancy may present with severe damage, which also constitutes an important public health problem due to the resulting high morbidity and mortality rates. Most congenitally infected newborn babies have

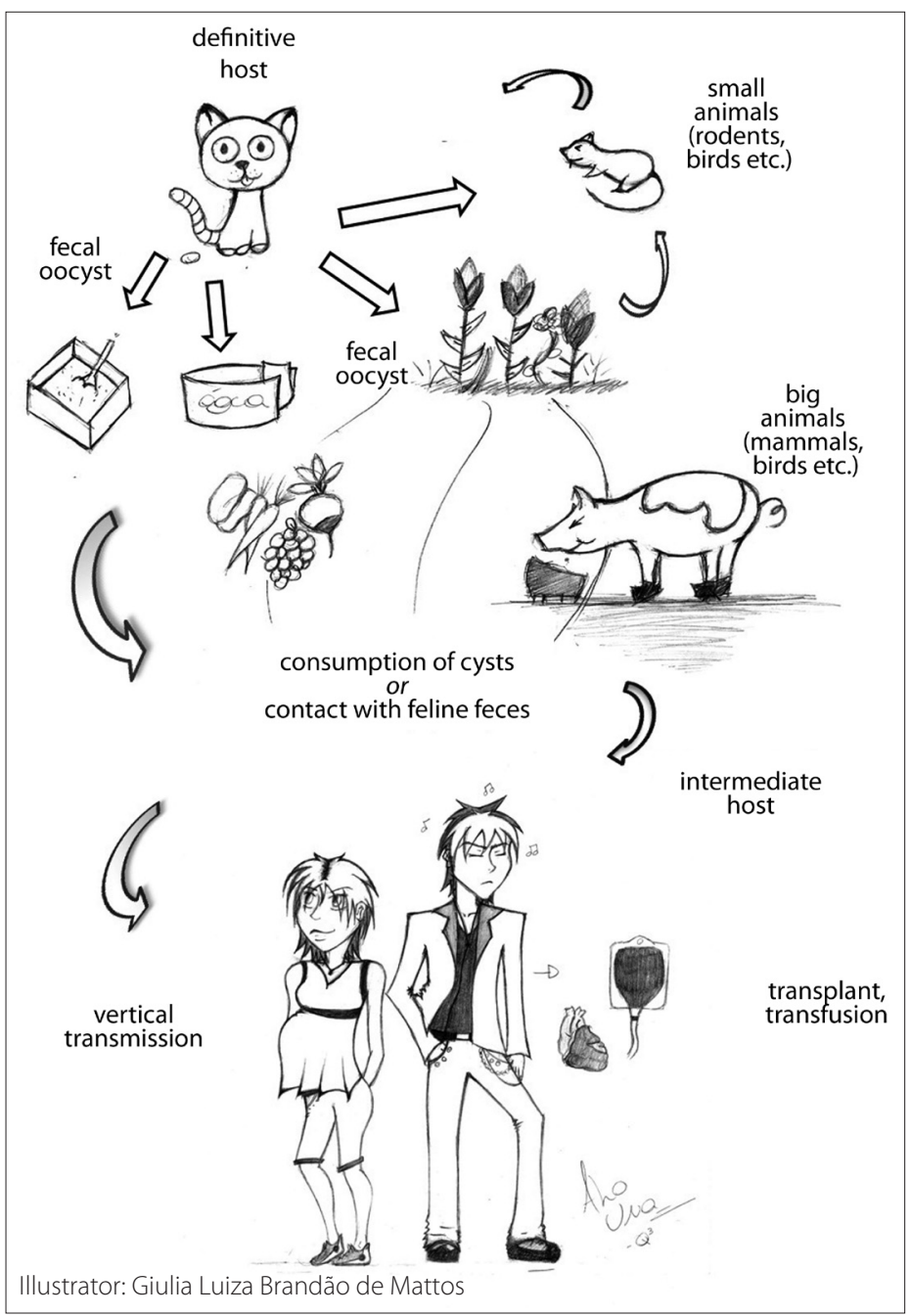

Figure 1. Toxoplasma gondii life cycle and human infection. no clinical signs but are at risk of developing retinochoroiditis during childhood or adolescence. ${ }^{4}$

The risk of fetal contamination and the severity of sequelae depend on the stage of pregnancy at which the mother becomes infected. ${ }^{4,5}$ Early in pregnancy, infections are less likely to cross the placental barrier, but when this does occur the consequences are more serious. In general, when infection occurs late in pregnancy, babies have mild symptoms or are asymptomatic at birth. ${ }^{6-8}$ High parasite counts in the amniotic fluid are associated with severe outcomes. ${ }^{8}$ However, time of infection during pregnancy is not the only factor that contributes towards the different outcomes, since parasitic virulence is also important with regard to the severity of the disease. ${ }^{9}$

Different studies have reported the seroprevalence of toxoplasmosis in pregnant women and newborns in different regions of the world, including South America. ${ }^{10}$ Additionally, Brazilian studies have demonstrated that infection rates among pregnant women vary according to the geographical region. ${ }^{10-16}$ However, there are only a few studies evaluating anti- $T$. gondii antibodies and their avidity in mothers and their newborns in the state of São Paulo. Further studies that analyze anti-T. gondii antibodies in paired mother-baby serum samples may contribute towards better understanding of congenital toxoplasmosis in specific regions. ${ }^{15,17}$

\section{OBJECTIVES}

The aim of this study was to evaluate the seropositivity of pregnant women and their newborn infants for anti-T. gondii immunoglobulin $M$ (IgM) and immunoglobulin G (IgG) antibodies. The pregnant women were attended at a reference outpatient clinic for high-risk pregnancies in São José do Rio Preto. This region, located in the northwest of the state of São Paulo, is composed of 96 municipalities with a population of around 1.5 million (Figure 2). ${ }^{18}$

\section{METHODS}

\section{Clinical samples}

This cross-sectional descriptive study analyzed the positivity of 174 serum samples for anti-T. gondii IgM and IgG antibodies and the avidity of IgG antibodies. From May 2005 to June 2007, 87 serum samples were collected from consecutive pregnant women at different gestational ages as follows: (i) 13 women in the first trimester; (ii) 36 women in the second trimester; and (iii) 38 women in the third trimester. Another 87 samples were collected from the babies' umbilical cords at birth. All the pregnant women selected for this study were considered as having "high-risk pregnancy", as determined by the Ministry of Health's policy. ${ }^{19}$ They were attended and gave birth at the high-risk gestational outpatient clinic of the teaching hospital (Hospital de Base) of Fundação Faculdade Regional de Medicina (Funfarme), 
São José do Rio Preto, state of São Paulo, Brazil. This is a tertiary-care regional reference center. The number of samples evaluated represented $23.7 \%$ of the total number $(\mathrm{n}=367)$ of highrisk pregnant women attended during the period of this study, as reported in our previous paper. ${ }^{20}$

After blood collection (around $5 \mathrm{ml}$ ) from mothers and from the umbilical cords, the samples were immediately sent to the Immunogenetics Laboratory of the Department of Molecular Biology, Faculdade de Medicina de São José do Rio Preto (Famerp). The serum samples were stored at $-20^{\circ} \mathrm{C}$ until use. All samples were assayed by means of indirect immunofluorescence (IIF) (for IgM and IgG), enzyme-linked immunosorbent assay (ELISA) (for IgG) and an avidity test. All the pregnant women gave their written consent for the procedures and the institution's Ethics Committee approved this study (case number 295/2008).

\section{Toxoplasma gondii and antigens}

T. gondii RH strain tachyzoites were grown and maintained in the ascites of Swiss mice by means of intraperitoneal inoculation. At three to four-day intervals after infection, peritoneal fluid from each mouse was collected in phosphate-buffered saline (PBS) solution at $\mathrm{pH}$ 7.2. The mixture was centrifuged at $1,000 \mathrm{~g}$ for 10 minutes. The sediment containing the parasites was washed twice in PBS, the parasites were counted and the concentration was determined in order to prepare the antigens. For IIF antigens, the centrifuge pellets were suspended in PBS at a concentration of $2 \times 10^{7}$ cells $/ \mathrm{ml}$. The tachyzoites were incubated in $2 \%$ buffered formalin for 30 minutes at $37{ }^{\circ} \mathrm{C}$, washed twice in PBS, centrifuged at $1,000 \mathrm{~g}$ for 10 minutes and finally fixed on glass slides. For ELISA, the crude extract of tachyzoites was obtained as previously described. ${ }^{21}$ The parasites were sonicated (10 cycles of 1.0 $\mathrm{A} /$ minute for five minutes with two-minute intervals). Subsequently, the aliquots were dissolved in $0.3 \mathrm{M} \mathrm{NaCl}$ (sodium chloride) and the protein concentration was determined in a Nanodrop ND1000 spectrophotomer.

\section{Serological reactions}

IIF was carried out as previously described, ${ }^{22}$ in order to determine whether anti-T. gondii IgG and IgM antibodies were present or absent. The samples were used in serial dilutions and assayed in duplicate. The dilutions went from 1:4 to 1:4096, and the cutoff point was determined as 1:16. For ELISA and the Toxoplasmaspecific IgG avidity assay, the samples were assayed in duplicate at a dilution of 1:500. The optical density (OD) cutoff for ELISA at a wavelength of $492 \mathrm{~nm}$ was 0.190 . The Toxoplasma-specific IgG avidity assay was performed as previously described. ${ }^{22}$ The basic ELISA test was used except that: (i) each serum sample was analyzed in two fourfold titration rows at a dilution of 1:500; (ii) after one hour of incubation at $37^{\circ} \mathrm{C}$, the first row was washed three times with $250 \mathrm{ml}$ of $6 \mathrm{M}$ urea in PBS containing $0.05 \%$

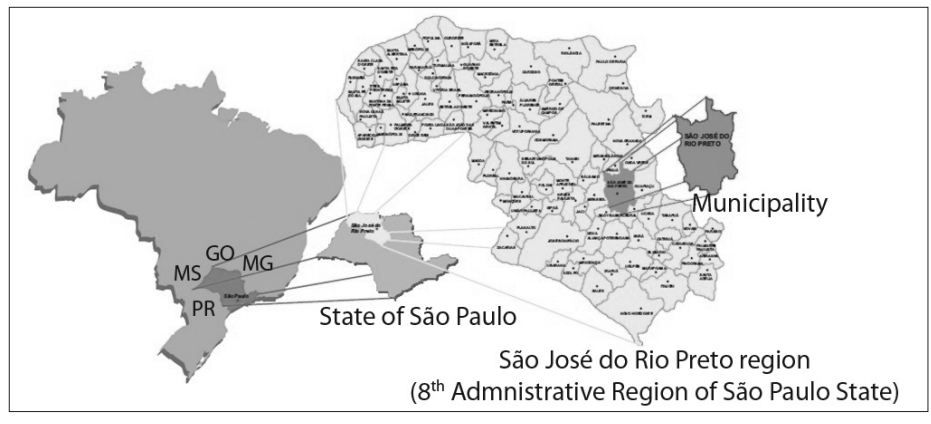

Figure 2. Map of Brazil indicating location of state of São Paulo and map of São José do Rio Preto region including 96 municipalities. ${ }^{18}$

Tween 20, in order to remove low-avidity antibodies from their binding sites. The control row was washed three times using the buffer without urea. The formula to calculate the IgG avidity index was: OD values under dissociative conditions/OD values of control without urea $\mathrm{x} 100$.

A low avidity index (up to 15\%) was indicative of an infection within the previous five months; an avidity index between 16 and $30 \%$ was indicative of an infection more than five months ago; and a high avidity index (over 30\%) represented chronic infection. For ELISA, the absorbance values were subtracted from the background, and the arithmetic mean was calculated. The cutoff was calculated for each reaction using a serum panel from 20 healthy individuals (data not shown).

\section{Statistical analysis}

Fisher's exact test was used to evaluate associations in the serological analysis, between maternal and newborn samples.

\section{RESULTS}

Among the 87 pregnant women evaluated, $43.7 \%(\mathrm{n}=38)$ were Caucasians, $44.8 \%(n=39)$ were of mixed race, $10.3(n=9)$ were blacks and $1.2 \%(\mathrm{n}=1)$ were Amerindians. The mean age and gestational age were 27.5 years $( \pm 6.9)$ and 25.5 weeks $( \pm 8.4)$, respectively.

Anti-T. gondii IgG antibodies, as determined by ELISA and IIF, were identified in $64.4 \%(56 / 87)$ of both the maternal and the umbilical cord serum samples. The samples from the other 31 pregnant women and their babies (35.6\%) were negative for toxoplasmosis. All the maternal serum samples except for two (2.3\%) were negative for anti-T. gondii IgM antibodies, as determined by IIF. In both of these cases, the antibodies were detected in the pregnant women during the third trimester of gestation. However, IgM antibodies were not isolated in the serum of the newborns, since fetuses are unable to produce IgM antibodies. ${ }^{14}$ These two pregnant women did not give their consent for amniotic fluid to be collected and therefore the fetal infection could not be confirmed by means of the polymerase chain reaction (PCR). 
The results showed that $92.9 \%$ (52/56) of the pregnant women infected with T. gondii had high avidity indexes for IgG antibodies ( $\geq 30 \%)$. Samples with avidity of less than $15 \%$ were not found. However, four serum samples had avidity indexes between 16 and $30 \%$. Of these, two samples were from pregnant women in the third trimester of pregnancy who were positive for anti-T. gondii IgM antibodies, and their babies had avidity indexes between 16 and $30 \%$. The other two women were in their second trimester of gestation and their babies presented avidity indexes of up to $30 \%$. The avidity indexes of the other serum samples from the umbilical cords were similar to those found in their mothers. These results are shown in detail in Table 1 . The results from the maternal and newborn serological analyses were not statistically significant (IIF/ELISA IgG: $\mathrm{P}=1.000$; IgG avidity: $\mathrm{P}=0.6788$ ).

\section{DISCUSSION}

Since toxoplasmosis is highly prevalent in Brazil and causes serious problems during pregnancy, ${ }^{10}$ we decided to investigate the serum status of a group of high-risk pregnant women with regard to anti-T. gondii IgM and IgG antibodies. These patients were attended and their babies were born at a high-risk pregnancy outpatient clinic in São José do Rio Preto. Our results showed that $64.4 \%$ of the women with high-risk pregnancies had toxoplasmosis. These data suggest that the rate of positive findings of T. gondii infection was high in this group and thus corroborate other studies from the same region of the state of São Paulo ${ }^{20,23}$ and from other Brazilian states. ${ }^{15-17,24-28}$ The similarities between this and other studies carried out in some Brazilian states ${ }^{15-17,28}$ may reflect homogeneity regarding the laboratory diagnostic strategies used.

The avidity index helps to identify the acute phase of infections by this parasite..$^{29}$ In this study, the majority of the infected women (92.9\%) were in the chronic phase of infection (avidity indexes higher than 30\%). Only anti-T. gondii IgG antibodies with high avidity were detected in serum samples from their babies. Since the avidity indexes were identical to those of the maternal serum and the methods used in this study were unable to differentiate
IgG antibodies from mothers and babies, it can be assumed that the antibodies presented by the newborns originated from the mothers. Therefore, the majority of the pregnant women evaluated in this study seemed to present a protective level of humoral immunity against $T$. gondii, without a risk of congenital transmission. Anti-T. gondii IgM antibodies were identified in $2.3 \%$ of the pregnant women. These antibodies were detected in the third trimester of gestation. Simultaneously, anti-T. gondii IgG had avidity indexes between 16 and $30 \%$. The data suggest that these women probably became infected around five months prior to testing; in other words, within the first trimester. When primary maternal infection occurs in this period, around $15 \%$ of the fetuses can become infected..$^{13,14,16}$ The fetuses of these two pregnant women were probably not infected during gestation, although this condition is not conclusive. There have been reports that $70 \%$ of newborns infected during gestation do not present symptoms at birth. ${ }^{30}$ Additionally, around 30\% of newborns do not demonstrate serological evidence of congenital infection at birth, even when the mothers present with IgM antibodies.,14

Since these data demonstrate that $2.3 \%$ of the pregnant women became infected during gestation, it can be assumed that this is the level of risk of congenital transmission of T. gondii in the northwestern region of the state of São Paulo. This figure corroborates our additional observations. ${ }^{23}$ These observations highlight the importance of early diagnosis and good-quality methodology for evaluating pregnant women and newborn babies in healthcare services. This, together with the risks implicit in congenital transmission, emphasizes the need for continuous educational programs and constant monitoring of pregnant women from regions where the prevalence of infection by this parasite is high.

Despite the small number of serum samples evaluated, the results from this study shed some light on the clinical importance of combined mother-newborn evaluation using serological methods to detect not only IgM and IgG anti-T. gondii antibodies but also IgG avidity. Furthermore, these results draw attention to the need to investigate patient samples consisting of larger

Table 1. Determination of anti-Toxoplasma gondii antibodies in maternal and umbilical cord serum samples using indirect immunofluorescence (IIF), enzyme-linked immunosorbent assay (ELISA) and an immunoglobulin G (IgG) avidity test, São José do Rio Preto, state of São Paulo, Brazil

\begin{tabular}{|c|c|c|c|c|c|c|c|}
\hline & \multicolumn{2}{|c|}{$\begin{array}{l}\text { IIF/ELISA IgG* } \\
\quad(n=174)\end{array}$} & \multicolumn{2}{|c|}{$\begin{array}{l}\text { IIF IgM } \\
(n=87)\end{array}$} & \multicolumn{3}{|c|}{$\begin{array}{l}\text { IgG avidity }{ }^{\dagger} \\
\quad(n=174)\end{array}$} \\
\hline & Negative & Positive & Negative & Positive & $\leq 15 \%$ & $16-30 \%$ & $\geq 30 \%$ \\
\hline Newborn & 31 & 56 & Not determined & Not determined & 0 & 2 & 54 \\
\hline Maternal & 31 & 56 & 85 & 2 & 0 & 4 & 52 \\
\hline $1^{\text {st }}$ trimester & 4 & 9 & 13 & 0 & 0 & 0 & 9 \\
\hline $2^{\text {nd }}$ trimester & 14 & 22 & 36 & 0 & 0 & 2 & 20 \\
\hline $3^{\text {rd }}$ trimester & 13 & 25 & 36 & 2 & 0 & 2 & 23 \\
\hline
\end{tabular}

${ }^{*} \mathrm{P}=1.000 ;{ }^{\dagger} \mathrm{P}=0.6788$ (calculated by means of Fisher's exact test)

IIF = indirect immunofluorescence; ELISA = enzyme-linked immunosorbent assay; IgG = immunoglobulin G; IgM = immunoglobulin $M$. 
numbers of mother-newborn pairs, given the epidemiological importance of toxoplasmosis.

\section{CONCLUSIONS}

This study demonstrated that $64.4 \%$ of the pregnant women in the northwestern region of the state of Sao Paulo became infected with T. gondii before pregnancy and that most of them had immune protection with high avidity indexes. Nonetheless, the study suggests that an epidemiologically significant proportion of the fetuses may be at risk of congenital transmission of T. gondii.

\section{REFERENCES}

1. Boothroyd JC. Toxoplasmosis. In: Moselio S. Encyclopedia of microbiology. $3^{\text {rd }}$ ed. Oxford: Elservier; 2009. p.732-43.

2. Munoz M, Liesenfeld O, Heimesaat MM. Immunology of Toxoplasma gondii. Immunol Rev. 2011;240(1):269-85.

3. Hill D, Dubey JP. Toxoplasma gondii: transmission, diagnosis and prevention. Clin Microbiol Infect. 2002;8(10):634-40.

4. Kaye A. Toxoplasmosis: diagnosis, treatment, and prevention in congenitally exposed infants. Journal of Pediatric Health Care. Available from: http://www.jpedhc.org/article/S08915245(10)00095-7/abstract. Accessed in 2011 (Mar 18).

5. Dunn D, Wallon M, Peyron F, et al. Mother-to-child transmission of toxoplasmosis: risk estimates for clinical counselling. Lancet. 1999;353(9167):1829-33.

6. Raeber PA, Berger R, Biedermann $K$, et al. La prévention de la toxoplasmose congénitale en Suisse. Texte de consensus du Groupe de travail "Toxoplasmose congénitale" de l'Office fédéral de la santé publique [Prevention of congenital toxoplasmosis in Switzerland. Consensus report of the study group "Congenital toxoplasmosis" of the federal public health office]. Schweiz Med Wochenschr Suppl. 1995;65:113S-120S

7. Hohlfeld P, Daffos F, Thulliez P, et al. Fetal toxoplasmosis: outcome of pregnancy and infant follow-up after in utero treatment. J Pediatr. 1989;115(5 Pt 1):765-9.

8. Romand S, Chosson M, Franck J, et al. Usefulness of quantitative polymerase chain reaction in amniotic fluid as early prognostic marker of fetal infection with Toxoplasma gondii. Am J Obstet Gynecol. 2004;190(3):797-802.

9. Peyron F, Lobry JR, Musset K, et al. Serotyping of Toxoplasma gondii in chronically infected pregnant women: predominance of type II in Europe and types I and III in Colombia (South America). Microbes Infect. 2006:8(9-10):2333-40.

10. Pappas G, Roussos N, Falagas ME. Toxoplasmosis snapshots: global status of Toxoplasma gondii seroprevalence and implications for pregnancy and congenital toxoplasmosis. Int J Parasitol. 2009:39(12):1385-94.

11. Avelino MM, Campos D Jr, Parada JB, Castro AM. Risk factors for Toxoplasma gondii infection in women of childbearing age. Braz J Infect Dis. 2004;8(2):164-74
12. Carmo ACZ, Bottom SR, Fleck J, Beck ST. Importância do rastreamento pré-concepcional e pré-natal da infecção por T. gondii; prevalência sorológica em um hospital público [The importance of screening preconception and antenatal T. gondii infection serological prevalence in a public hospital]. Rev Bras Anal Clin. 2005;37(1):49-52.

13. Castilho-Pelloso MP, Falavigna DLM, Araújo SM, Falavigna-Guilherme AL. Monitoramento de gestantes com toxoplasmose em serviços públicos de saúde [Monitoring of pregnant women with toxoplasmosis in public health services]. Rev Soc Bras Med Trop. 2005;38(6):532-3.

14. Reis MM, Tessaro MM, D'Azevedo PA. Toxoplasma-lgM and lgG-avidity in single samples from areas with a high infection rate can determine the risk of mother-to-child transmission. Rev Inst Med Trop São Paulo. 2006:48(2):93-8

15. Carellos EVM, Andrade GMQ, Aguiar RALP. Avaliação da aplicação do protocolo de triagem pré-natal para toxoplasmose em Belo Horizonte, Minas Gerais, Brasil: estudo transversal em puérperas de duas maternidades [Evaluation of prenatal screening for toxoplasmosis in Belo Horizonte, Minas Gerais State, Brazil: a cross-sectional study of postpartum women in two maternity hospitals]. Cad Saúde Pública $=$ Rep Public Health. 2008;24(2):391-401.

16. Lago EG, Carvalho RL, Jungblut R, Silva VB, Fiori RM. Screening for Toxoplasma gondii antibodies in 2,513 consecutive parturient women and evaluation of newborn infants at risk for congenital toxoplasmosis [Triagem para anticorposanti-Toxoplasma gondii em 2. 513 parturientes consecutivas e avaliação dos recém-nascidos com risco de toxoplasmose congênita]. Sci Med. 2009;19(1):27-34.

17. Lago EG,NetoEC,Melamed J,etal.Congenital toxoplasmosis: late pregnancy infections detected by neonatal screening and maternal serological testing at delivery. Paediatr Perinat Epidemiol. 2007;21(6):525-31.

18. Prefeitura Municipal de São José do Rio Preto. Secretaria de Planejamento e Gestão Estratégica. Setor de Estudos Socieconômicos. Conjuntura Econômica de São José do Rio Preto 2009. Available from: http://www.riopreto.sp.gov.br/PortalGOV/do/subportais_ Show?c=146. Accessed in 2011 (Mar 4).

19. Brasil. Ministério da Saúde. Secretaria de Atenção à Saúde. Departamento de Ações Programáticas Estratégicas. Área Técnica de Saúde da Mulher. Pré-natal e puerpério: atenção qualificada e humanizada - manual técnico. Brasilia: Ministério da Saúde; 2005. Available from: http://portal.saude.gov.br/portal/arquivos/pdf/ manual_puerperio_2006.pdf. Accessed in 2011 (Mar 4).

20. Mattos CCB, Cintra JR, Ferreira AIC, et al. Lack of association between ABO histo-blood groups, secretor and non-secretor phenotypes, and anti-Toxoplasma gondii antibodies among pregnant women from the northwestern region of Sao Paulo State, Brazil. Archives of Medical Science. 2008;4(3):254-8. Available from: http://www.termedia.pl/ Journal/-19/Streszczenie-11195. Accessed in 2011 (Mar 4).

21. Meira CS, Costa-Silva TA, Vidal JE, et al. Use of the serum reactivity against Toxoplasma gondii excreted-secreted antigens in cerebral toxoplasmosis diagnosis in human immunodeficiency virus-infected patients. J Med Microbiol. 2008;57(Pt 7):845-50. 
22. Colombo FA, Vidal JE, Penalva de Oliveira AC, et al. Diagnosis of cerebral toxoplasmosis in AIDS patients in Brazil: importance of molecular and immunological methods using peripheral blood samples. J Clin Microbiol. 2005;43(10):5044-7.

23. Gonçalves MA, Matos CCB, Spegiorin LC, et al. Seropositivity rates for toxoplasmosis, rubella, syphilis, cytomegalovirus, hepatitis and HIV among pregnant women receiving care at a public health service, São Paulo State, Brazil. Braz J Infect Dis. 2010;14(6):601-5.

24. Spalding SM, Amendoeira MRR, Klein CH, Ribeiro LC. Serological screening and toxoplasmosis exposure factors among pregnant women in South of Brazil. Rev Soc Bras Med Trop. 2005;38(2):173-7.

25. Vaz AJ, Guerra EM, Ferratto LCC, Toledo LAS, Azevedo Neto RS. Sorologia positiva para síflis, toxoplasmose e doença de Chagas em gestantes de primeira consulta em centros de sáude da área metropolitana, Brasil [Positive serology of syphilis, toxoplasmosis and Chagas' disease in pregnant women in their first visit to state health centres in a metropolitan area, Brazil]. Rev Saúde Pública. 1990;24(5):373-9.

26. Cerqueira RL, Kawarabayashi M, Guimarães AC, et al. Santo Inácio revisited: protozoan diseases in an isolated village in northeastern Brazil after twenty years. Am J Trop Med Hyg. 1998;59(5):736-40.

27. Rey LC, Ramalho ILC. Seroprevalence of toxoplasmosis in Fortaleza, Ceara, Brazil. Rev Inst Med Trop São Paulo. 1999:41(3):171-4.

28. Figueiró-Filho EA, Senefonte FRA, Lopes AHA, et al. Freqüência das infecções pelo HIV-1, rubéola, síflis, toxoplasmose, citomegalovírus, herpes simples, hepatite $B$, hepatite $C$, doença de Chagas e HTLV I/II em gestantes, do Estado do Mato Grosso do Sul [Frequency of HIV-1, rubella, syphilis, toxoplasmosis, cytomegalovirus, simple herpes virus, hepatitis B, hepatitis C, Chagas disease and HTLV I/II infection in pregnant women of State of Mato Grosso do Sul]. Rev Soc Bras Med Trop. 2007:40(2):181-7.

29. Figueiró-Filho EA, Nanni Junior C, Almeida GB, et al. Toxoplasmose aguda: revisão de métodos diagnósticos baseada em evidências e proposta de protocolo de seguimento durante a gestação [Acute toxoplasmosis: a review of diagnostic methods based in evidences and a proposal of management during pregnancy]. Femina. 2007;35(111):723-9.

30. Petersen E, Pollack A, Reiter-Owona I. Recent trends in research on congenital toxoplasmosis. Int J Parasitol. 2001;31 (2):115-44.
Acknowledgements: Thanks to David Hewitt for the English version and Giulia Luiza Brandão de Mattos for the Figure 1

Conflict of interest: None

Sources of funding: This study received financial support from the Fundação de Amparo à Pesquisa do Estado de São Paulo (Fapesp2008/09311-0; 2009/09168-6) and a research grant from the Bolsa de Auxílio à Pesquisa da Faculdade de Medicina de São José do Rio Preto (BAP-Famerp). Cinara de Cássia Brandão de Mattos, Ana lara da Costa Ferreira, Cristina da Silva Meira, Thaís da Costa Silva and Fabiana Nakashima received grants from the Brazilian Ministry of Education (Coordenação de Aperfeiçoamento de Pessoal de Nível SuperiorDemanda Social, Capes-DS).

Date of first submission: July 19, 2010

Last received: March 17, 2011

Accepted: April 1, 2011

\section{Address for correspondence:}

Luiz Carlos de Mattos

Laboratório de Imunogenética

Departamento de Biologia Molecular

Faculdade de Medicina de São José do Rio Preto - Famerp

Av. Brigadeiro Faria Lima, 5.416

Vila São José — São José do Rio Preto (SP) — Brasil

CEP 15090-000

Tel. (+55 17) 3201-5854

Fax. (+55 17) 3229-1777

E-mail: luiz.carlos@famerp.br

E-mail: imunogenetica.famerp@gmail.com 